\title{
Scale Tests to Estimate Penetration Force and Stress State of the Silica Sand in Windfarm Foundations
}

\author{
Jorge Soriano Vicedo ${ }^{1, *}$, Javier García Barba ${ }^{1, *}$, Jorge Luengo Frades ${ }^{2, *}$ and Vicente Negro Valdecantos ${ }^{2, *}$ \\ 1 Departamento de Ingeniería Civil, Escuela Politécnica Superior, Universidad de Alicante, \\ 03690 Alicante, Spain \\ 2 Escuela Tecnica Superior de Ingenieros de Caminos, Canales y Puertos, Universidad Politécnica de Madrid, \\ 28040 Madrid, Spain \\ * Correspondence: jsv12@alu.ua.es (J.S.V.); javier.garciabarba@mscloud.ua.es (J.G.B.); jlf17@alu.ua.es (J.L.F.); \\ vicente.negro@upm.es (V.N.V.)
}

check for

updates

Citation: Vicedo, J.S.; Barba, J.G.; Frades, J.L.; Valdecantos, V.N. Scale Tests to Estimate Penetration Force and Stress State of the Silica Sand in Windfarm Foundations. Energies 2021, 14, 5904. https://doi.org/10.3390/ en14185904

Academic Editors: João Carlos de Campos Henriques

and Puyang Zhang

Received: 24 June 2021

Accepted: 13 September 2021

Published: 17 September 2021

Publisher's Note: MDPI stays neutral with regard to jurisdictional claims in published maps and institutional affiliations.

Copyright: (c) 2021 by the authors. Licensee MDPI, Basel, Switzerland. This article is an open access article distributed under the terms and conditions of the Creative Commons Attribution (CC BY) license (https:// creativecommons.org/licenses/by/ $4.0 /)$.
Abstract: The analysis of the soil behavior when the pile is driving into the seabed in offshore wind platforms is one of the major problems associated with this new form of clean energy generation. At present, there are no scaled studies carried out analyzing the mechanical and deformational behavior of both the material of the pile supporting the engine (large steel hollow piles with a diameter of $8 \mathrm{~m}$ and a thickness of $15-20 \mathrm{~cm}$ ) and the soil where the pile is driven. Usually, these elements are installed on sands with a very small grain size displaced from the limits of dry-wet beach (water limit) toward the offshore limits, which prevents them from returning to their previous location in a natural way. This paper presents results obtained from scale tests in a steel pool to analyze the behavior of the sand where the piles were installed. First, the California Bearing Ratio (CBR) test was carried out to estimate the soil behavior in similar conditions to the steel pool. The scale tests consisted of the penetration of the steel tube into the sand using a hydraulic press. The objective was to compare the results for three tubes with different diameters, three different speeds, and two kinds of ending on the extreme of the tested element.

Keywords: offshore; windfarm; foundation; scale test; CBR; silica sand

\section{Introduction}

The target of this article was to analyze the mechanical and deformational behavior of the soil and study the results from scale tests carried out to estimate penetration force into and stress state of the soil, as well as its application to real driven works for monopile foundation. At present, the monopile foundation covers $81 \%$ of the foundation typology of all wind farms installed in the world (Figure 1). One of the important advantages of this typology is its cost of fabrication, which is cheaper than other typologies such as jackets. In addition, the installation of a monopile is easy to execute [1,2]. However, there are no full-scale trials at sea analyzing the behavior of the seabed, and the trials carried out onshore did not take into account the geotechnical characteristics of the soil being very different to that existing in the seabed. This is one of the conditioning factors, along with the several phenomena (such as marine currents, high pressures due to great depth, corrosion, and etc. [3,4]) that lead to monopile foundations being currently oversized to ensure the stability of the structure. These structures reach weights of about 600 tons, diameters of $8 \mathrm{~m}$, and thicknesses up to $15 \mathrm{~cm}$ [5-13]. In many cases, these structures are driven up to $30 \mathrm{~m}$ into the seabed [14]. 

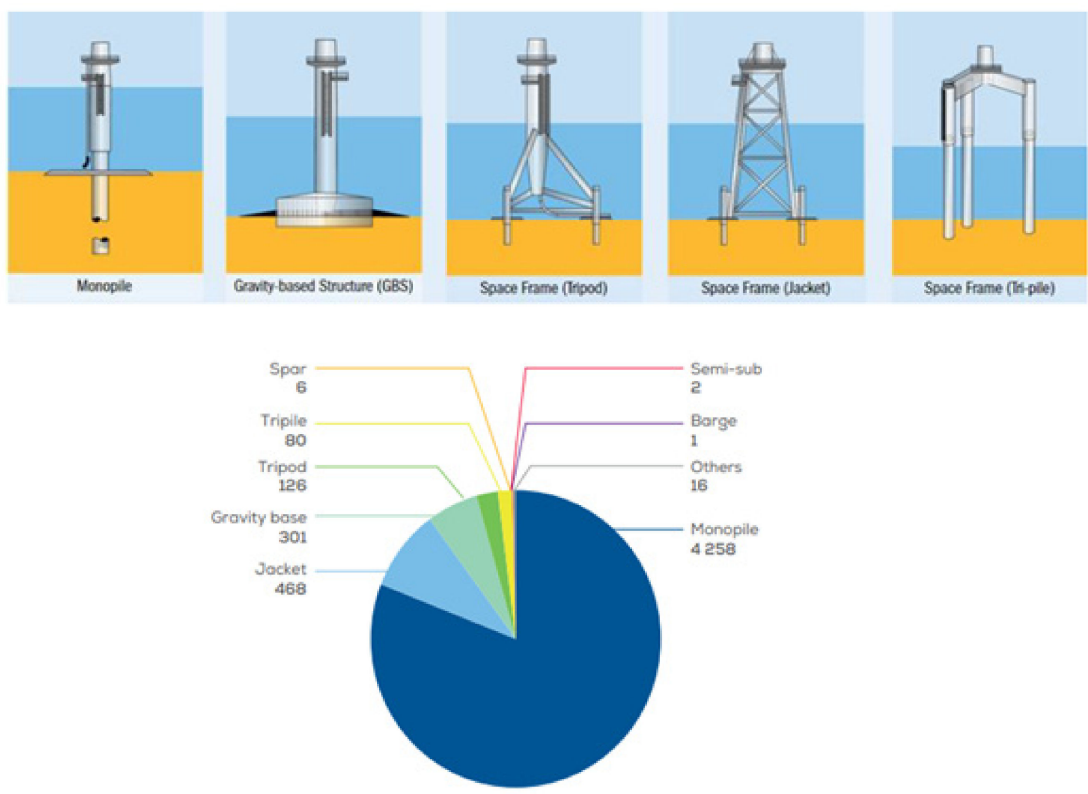

Figure 1. Typical fixed offshore wind farm foundations and comparison of the share in 2018. Source: Wind Europe.

It is worth determining the behavior of the base material on which the turbines are installed (sands). These sands are transported from the coast and settle on the seabed over time [15-19]. The sediment is composed of different grain size fractions, and each fraction has a particular distribution across the littoral profile. The maximum in the relative distribution is located around the shoreline ( $0 \mathrm{~m}$ depth), which decreases toward the dune and offshore, up to $6 \mathrm{~m}$ depth, where its percentage increases seaward again. The coarsest fraction $(>350 \mu \mathrm{m})$ shows a discontinuity in its distribution because it is hardly represented in the sediment between 6 and $10 \mathrm{~m}$ depth. The finest fraction (100-150 pm) shows a continuously increasing distribution from the shoreline in an offshore direction, and the gradient becomes steeper at $600 \mathrm{~m}$ from the shoreline [20].

Sand with a grain size $>500 \mathrm{~mm}$ was not supplied by the factories. Therefore, a size of $760 \mathrm{~mm}$ was chosen. In addition, the D50 was negligible compared to the tube's thickness.

At present, a large number of tests such as those of PISA (Pile Soil Analysis) [15] have been carried out. The PISA project involves entities such as the Royal Geographical Society, British Petroleum, or the Norwegian Institute. The PISA project consists of several tests of scale pile driving to determine the behavior of the soil. These tests, for a foundation study of marine turbines, were carried out onshore (Figure 2).

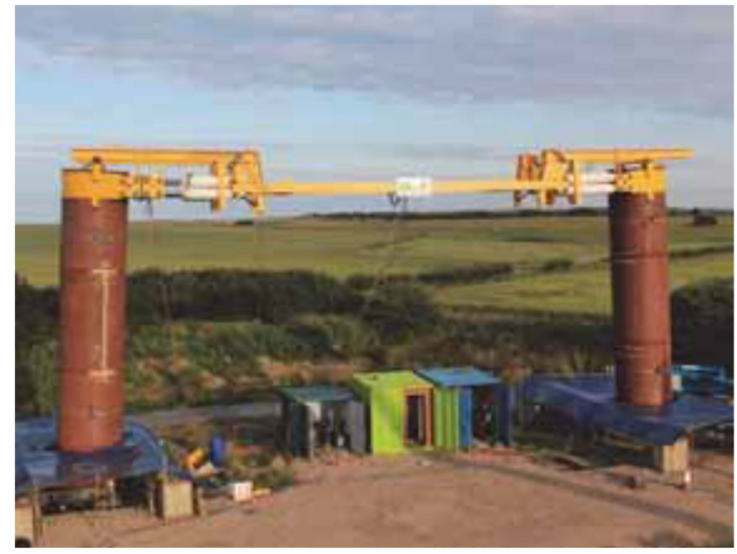

Figure 2. PISA project. 
Figure 3 shows an overview of activity for the PISA project [15]. The PISA project features important activities such as the design of field tests, field tests, validation, design method (FE), or full-scale prediction of onshore tests. In this paper, the red area in Figure 3 was the focus for making changes (described in Section 2.2) with respect to the PISA project (site investigation, design of field tests, draft parameterized method, calibration, field tests, validation).

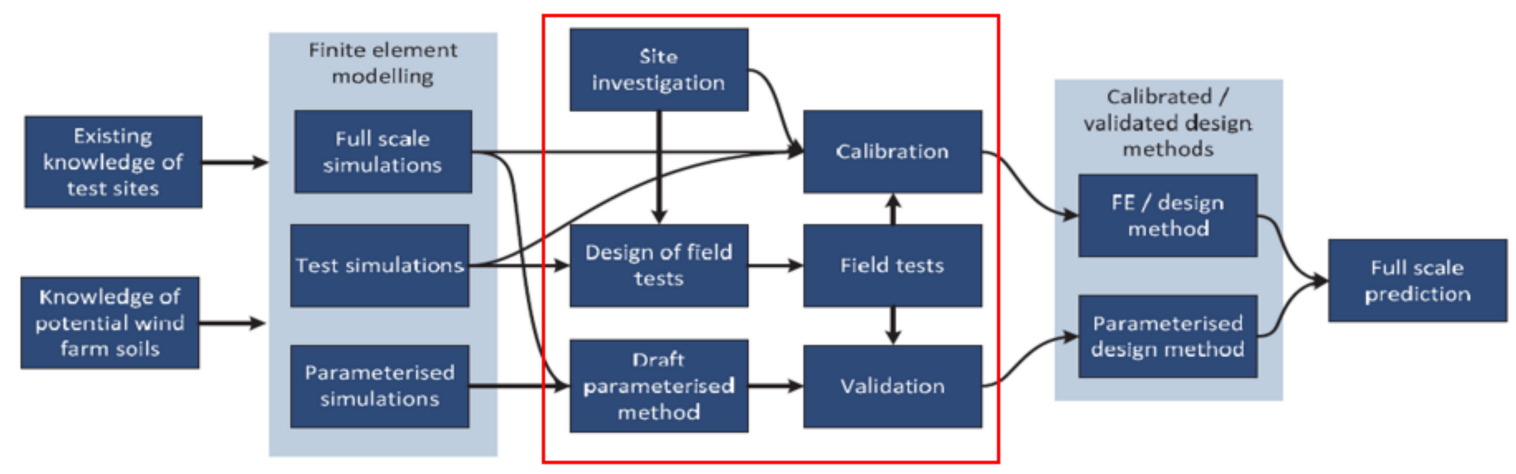

Figure 3. Overview of activity for the PISA project.

The analysis of the results of this article provide the opportunity to develop a future project. Some finite element models were carried out with Plaxis (special software with finite elements for soil mechanical behavior). Using this software, we could analyze scale tests inside a pool. It is possible to model several sizes and diameters of the sand particles, as well as the drive simulation of piles, in dry and submerged conditions. In addition, submerged tests inside the laboratory were made in the presence of water.

One of the most important conclusions obtained from the PISA project was that the application of a design approach indicated potential for a significant reduction in design conservatism and substantial savings for selected design scenarios. In addition, the field tests and the supporting site characterization delivered a new industry standard database against which design models in clay and sand may be compared, developed, and validated. Lastly, the adoption of the PISA design approach is likely to result in reduced conservatism in monopile design and better economies for wind farm development.

However, the existing research findings on this topic are not sufficient due to the difficulty in producing a scale test. Thus, the main objective of this paper was to produce some scale tests which include characteristics and restrictions identified by PISA, as described in Section 2.2.1.

\section{Materials and Methods}

\subsection{Previous Tests}

The sand chosen was silica sand due to its similarity to sea sand. Four tons of silica sand and a ton of limestone sand were used because silica sand does not have a large amount of fines, whereas sea sand contains fines [20]. Each test included three samples to improve the accuracy of the results, and all of them were tested using the same parameters of the scale tests.

The sand's parameters were the same as those used in the scale test in the laboratory. There are no optimal soil conditions for these tests. The moisture content of the samples was not defined because it cannot be chosen during in situ sea tests.

In this paper, we carried out a granulometric analysis, density test, direct shear test using a direct shear test apparatus, triaxial shear test using the cell of a triaxial apparatus, and tensile test. 


\subsubsection{Granulometric Analysis}

The study was carried out according to the UNE-EN 933-1 standard [21]. The objective was to determine the basic granulometric characteristics characterizing the sand, such as the granulometric curves (Figure 4). The vertical axis shows the percentage of grains passing through a mesh according to UNE 103101:1995 and ASTM D6913 [22,23]. The most important parameters obtained were as follows:

- Average grain diameter (D50): $0.769 \mathrm{~mm}$.

- Uniformity coefficient $(\mathrm{Cu}): 2.935$.

- Coefficient of curvature $(C c): 1.367$.

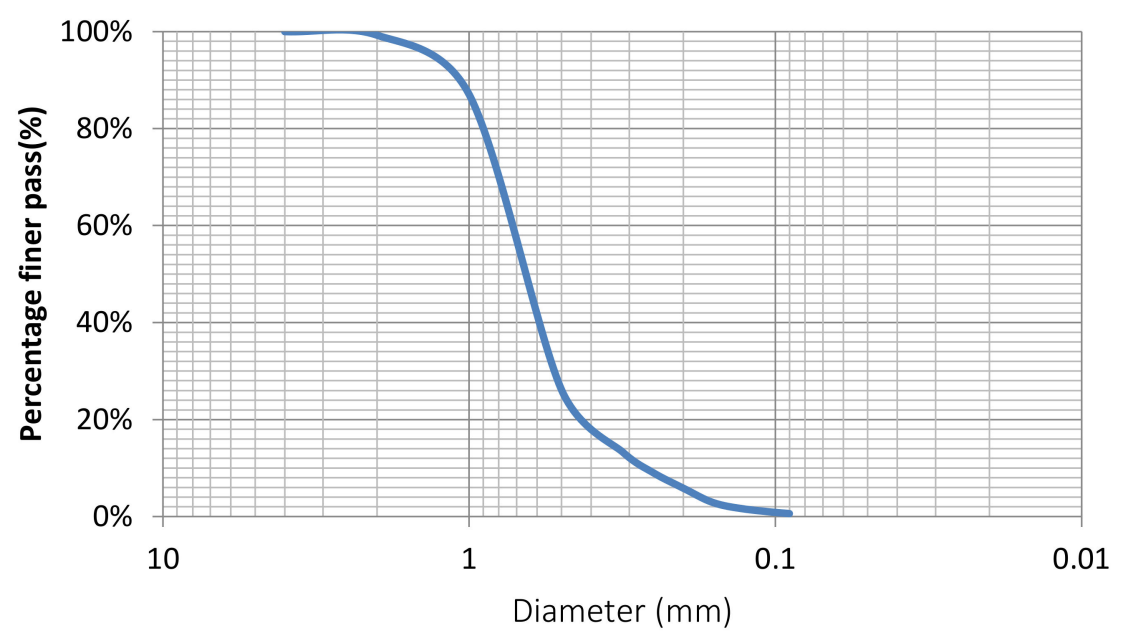

Figure 4. Distribution of grain size.

D50 is an important parameter for the characterization of sand and the definition of coastal movement $[24,25]$. Furthermore, this parameter allows comparing the sand with other tests carried out at sea. Well-graded soils have coefficient of curvature values between 1 and 3, and a sand with a uniformity coefficient less than 3 is considered very uniform [22].

\subsubsection{Density Test}

The density test was carried out according to the UNE-EN 1097-6 standard [26] for sand samples. Three samples of sand were tested. Table 1 shows the values of the density of the mixed sand.

Table 1. Density value of sand.

\begin{tabular}{cccc}
\hline & Sample 1 & Sample 2 & Sample 3 \\
\hline$\rho_{\text {sand }}\left(\mathrm{g} / \mathrm{cm}^{3}\right)$ & 2.615 & 2.628 & 2.639 \\
$\rho_{\text {sand,average }}\left(\mathrm{g} / \mathrm{cm}^{3}\right)$ & - & - & 2.626 \\
\hline
\end{tabular}

\subsubsection{Direct Shear Test}

The direct shear test was carried out according to the UNE 103401 standard [27] for silica sand samples. The test used was the consolidate drained (CD) method, recommended for granular soils [28].

For the preparation of the sample, the sand was poured into a box, ensuring a great enough fall height to prevent compaction (Figure 5). This option was chosen to test the material in conditions that would be found on the seabed, on which the material is deposited by its own weight. According to the standard, consolidation occurs almost instantaneously in sandy soils; hence, a speed of $1 \mathrm{~mm} / \mathrm{min}$ was chosen with a break lasting between 5 and $10 \mathrm{~min}$. 


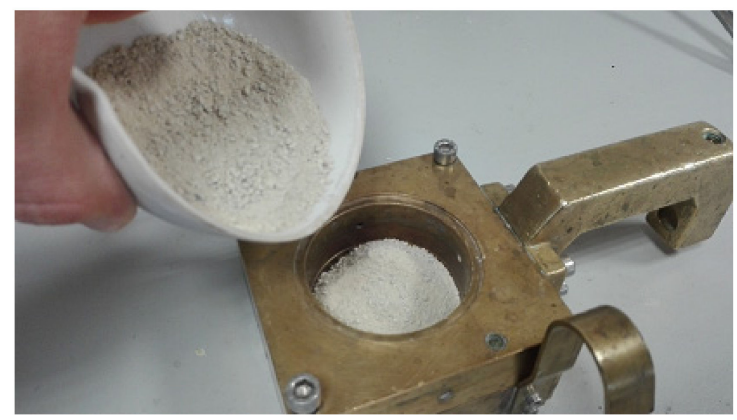

Figure 5. Pouring the sand into the box.

Figure 6 shows the graph of the tension relationship, which determines the friction angle and the cohesion (Table 2).

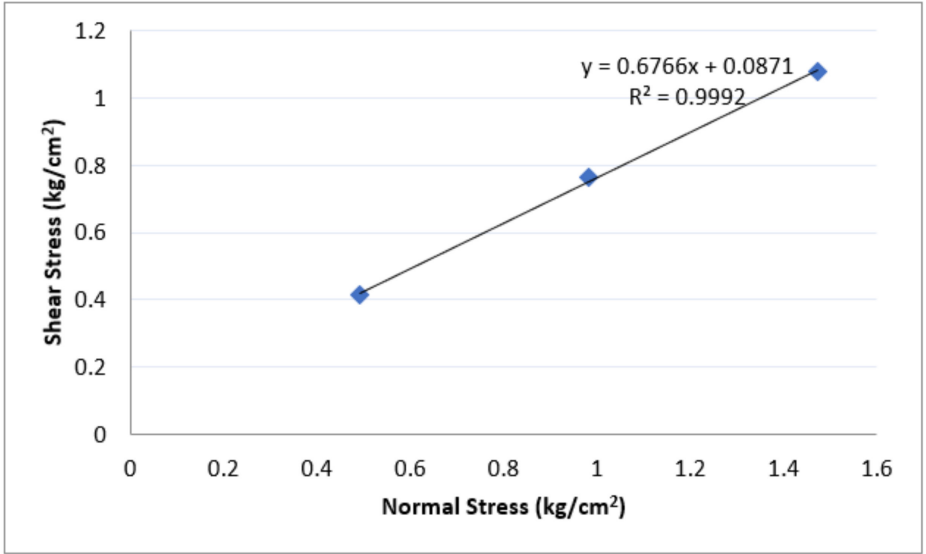

Figure 6. Shear and normal stress of sand.

Table 2. Total parameters of sand.

\begin{tabular}{cc}
\hline Friction angle $(\phi)$ & $34.08^{\circ}$ \\
Cohesion $(c)$ & $\sim 0 \mathrm{~kg} / \mathrm{cm}^{2}$ \\
\hline
\end{tabular}

\subsubsection{Triaxial Shear Test}

The triaxial shear test was carried out according to the UNE-EN ISO 17892-9:2019 standard [29] for silica sand samples (Figure 7). According to this standard, consolidation occurs almost instantaneously in sandy soils; hence, the time of consolidation was 1-3 h.

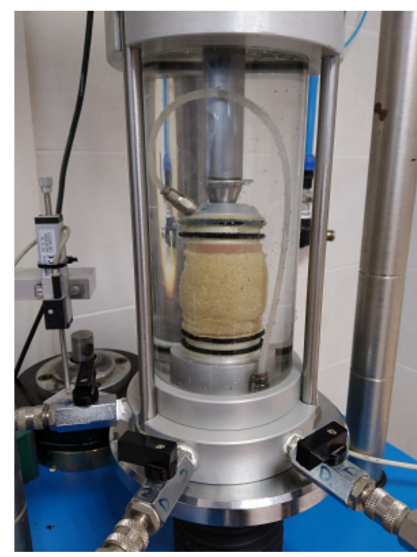

Figure 7. Silica sand sample subjected to pressure in a triaxial cell. 
The Young's modulus $(E)$ of the sand was calculated as approximately $21,570 \mathrm{kN} / \mathrm{m}^{2}$. This can be obtained as a function of the triaxial test values, either at the beginning of the stress-strain curve or at $50 \%$ of the maximum stress. In this case, it was estimated at $50 \%$ of the maximum stress, as typically employed in this sort of test [30-32].

\subsubsection{Tensile Test}

The tensile test was carried out according to the UNE-EN ISO 6892-1:2020 standard [33] for the material of the tubes tested (Table 3).

Table 3. Breakings values of steel of the tubes.

\begin{tabular}{ccc}
\hline & Breaking Load (kN) & Breaking Strain (MPa) \\
\hline Sample 1 & 16.50 & 458.35 \\
Sample 2 & 16.61 & 461.34 \\
Sample 3 & 16.56 & 459.98 \\
Average & 16.56 & 459.89 \\
\hline
\end{tabular}

\subsection{Scale Tests}

\subsubsection{PISA Model: Dimensions and Speed Test}

In the PISA project [15], 28 piles were tested with varied diameter, length, and wall thickness using both monotonic and cyclic loads. The field tests represent a new industry standard database against which design models for piles in clay and sand may be compared and validated.

Ideally, full-scale offshore tests using 6-10 m diameter piles would be used to benchmark the new design methodologies. However, due to the high cost of testing offshore and the technical constraints of equipment that can be mobilized, onshore testing was accepted at reduced scale. Scaled pile geometries and loading regimes were adopted, which were representative of offshore wind foundations (Figure 8).

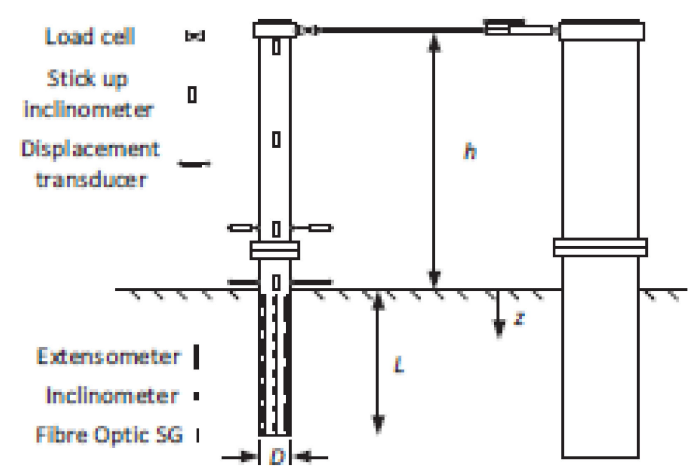

Figure 8. Diagram of PISA project.

The parameters used were as follows:

- $\quad$ Pile diameters of $0.273 \mathrm{~m}, 0.762 \mathrm{~m}$, and $2.0 \mathrm{~m}$,

- Embedded lengths between $1.43 \mathrm{~m}$ and $10.5 \mathrm{~m}$, providing a range of standard length $3<L / D<10$,

- Wall thicknesses $7 \mathrm{~mm}$ to $38 \mathrm{~mm}$, providing a range of standard thickness $30<D / t<80$,

- Speed load of $D / 300$ or $D / 500$ per minute,

where $L$ is the embedded length, $D$ is the diameter, $t$ is the thickness, $h$ is the nonembedded length, and $z$ is the depth reference.

\subsubsection{CBR Test}

The Californian Bearing Ratio Test (CBR Test) was carried out according to the UNE 103502 standard [34] for silica sand samples [28]. 
The objective of this test was to determine an estimation of sand penetration using a piston with similar characteristics to the piles of the scale test. The CBR test was carried out using three types of compaction (15, 30, and 45 hits), as outlined in the standard (Figure 9).

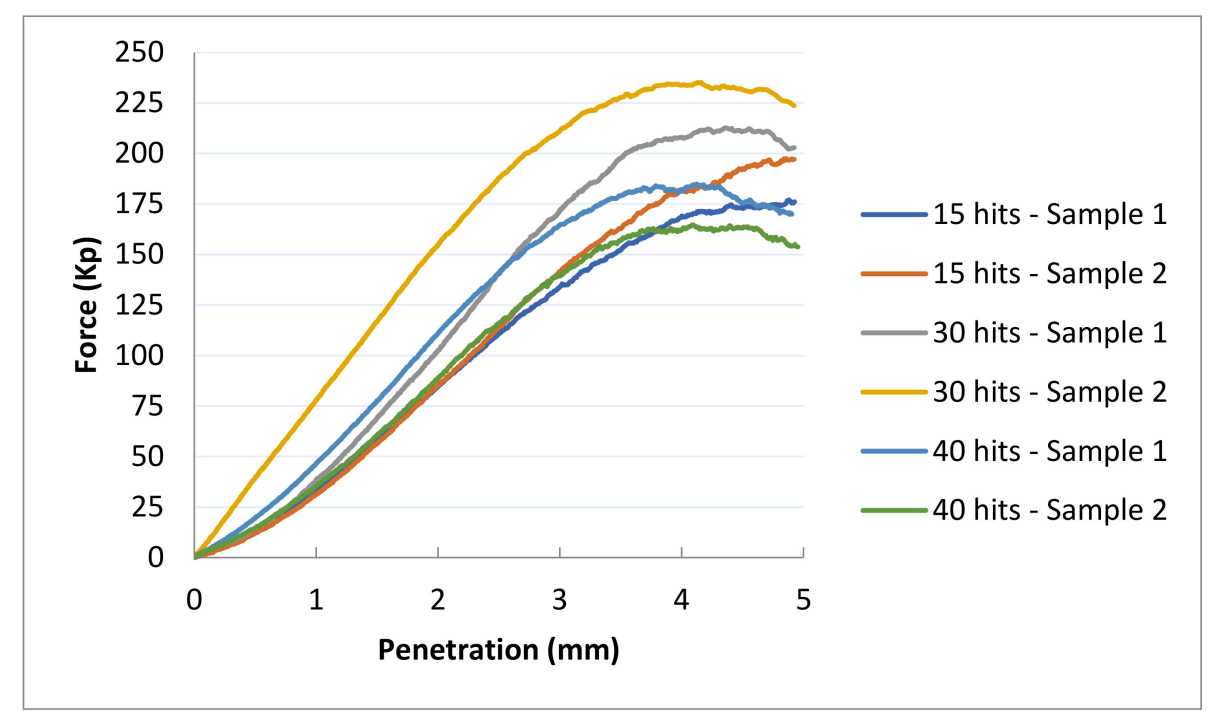

Figure 9. CBR test using each compaction $(15,30$, and 45 hits).

These obtained results can serve as an estimate for the raft tests considering relevant aspects from the scale results [35].

\subsubsection{Characteristics and Dimensions of Scale Test}

- $\quad$ The pool dimensions were as follows (Figure 10):

$2 \times 2 \times 1 \mathrm{~m}$ steel pool with $5 \mathrm{~mm}$ thickness,

Lower plate of $2.3 \times 2.3$ with $3 \mathrm{~mm}$ thickness that served as the base of the pool, $50 \mathrm{~cm}$ high triangular stiffener increasing the stiffness in two directions.

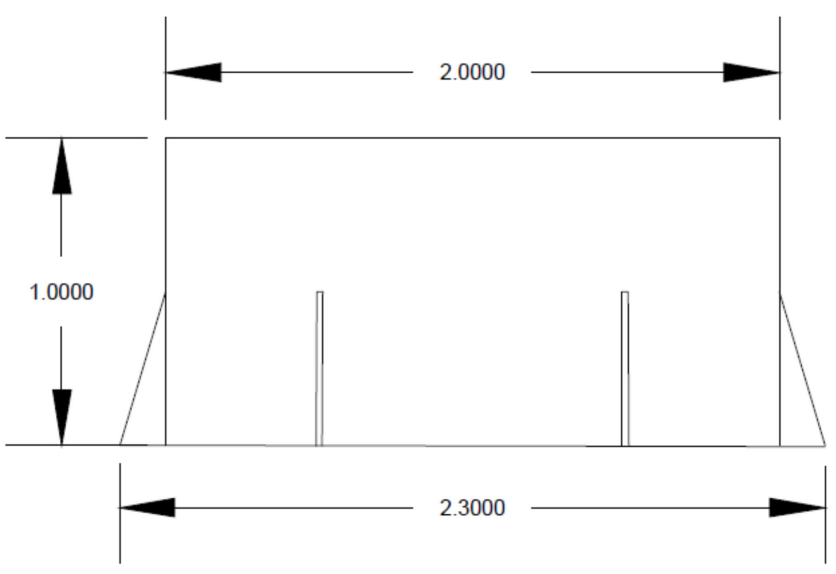

Figure 10. Outline of the pool in meters.

These pool dimensions were enough to avoid the contour effects with the side walls and the floor Furthermore, there is no standardized test to be found in the ABS or DNV-GL.

The gauge layout is shown in Figure 11. 


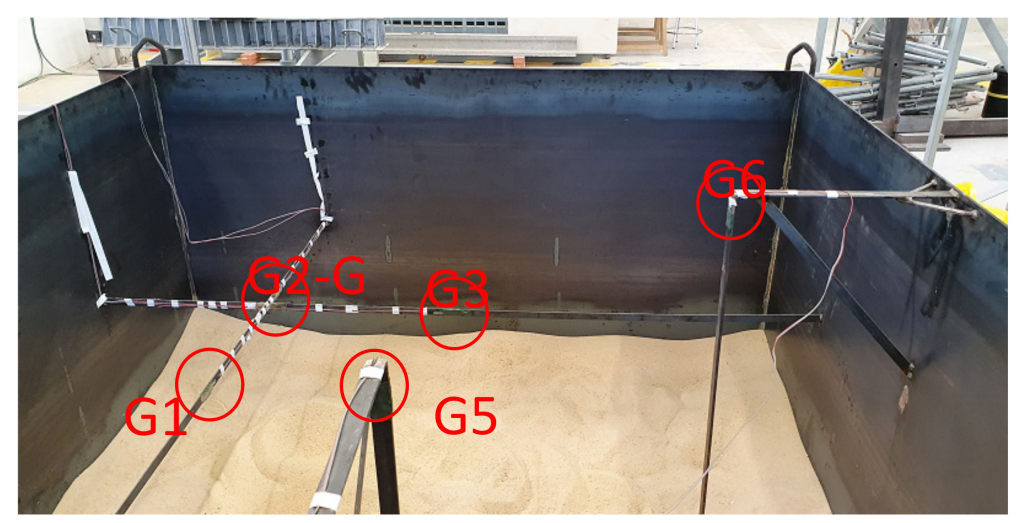

Figure 11. Gauge layout in pool.

The gauges were placed on strips perpendicular to each other, installed at a height of $50 \mathrm{~cm}$ halfway between the center of the pool and the side, as can be seen in Figure 11.

Three tubes were employed with the characteristics described in Table 4.

Table 4. Tube dimensions and PISA restrictions.

\begin{tabular}{cccc}
\hline Dim. in $\mathbf{~ m m}$ & Tube $\mathbf{1}$ & Tube 2 & Tube 3 \\
\hline L, total (Lt) & 910 & 700 & 600 \\
L, embedded (Le) & 450 & 375 & 350 \\
Diameter (D) & 194 & 115 & 80 \\
Thickness (t) & 4 & 3 & 3 \\
$3<$ Le/D $<10$ & 2.3 & 3.26 & 4.06 \\
$30<\mathrm{D} / \mathrm{t}<80$ & 48.5 & 38.3 & 26.7 \\
\hline
\end{tabular}

As can be seen in Table 4, the thicknesses chosen for this test achieved the restrictions given by the PISA test [36] (mentioned in Section 2.2.1) The tubes chosen were not excessively large, and their thicknesses can easily be found in factories. In addition, the tubes were closed at one end. A hollow position denotes where the driving is carried out using the open side, and the flat position denotes where it is carried out using the closed side.

The penetration speeds for the tests were different from the PISA project, where $D / 300$ per minute and $D / 500$ per minute were chosen $(D=$ diameter). In our case, these speeds reproduced very long tests. Therefore, an estimate was made on the basis of the three diameters, and speeds of 5, 10 and $20 \mathrm{~mm} / \mathrm{min}$ were obtained with test durations of $1 \mathrm{~h}$, $30 \mathrm{~min}$, and $15 \mathrm{~min}$, respectively [37].

The depth of penetration chosen was $325 \mathrm{~mm}$. This length was sufficient to determine the mechanical behavior of the steel tube with the sand and, thus, avoid contour effects.

\subsubsection{Scale Test}

This test consisted of the penetration of the steel tube into the sand using a hydraulic press (Figure 12). To avoid eccentricities, a distribution plate was placed in the upper area of each tube. The nomenclature used for each test was as follows: H-F (hollow-flat) position, 80-115-194 mm (three tube diameters), and 5-10-20 mm/min (three speeds) [10,38]. The most important problem was the compaction of the soil each time a penetration was carried out. To solve this problem, the sand was decompressed using a kneading machine to release the sand particles (Figure 12b) [39]. 


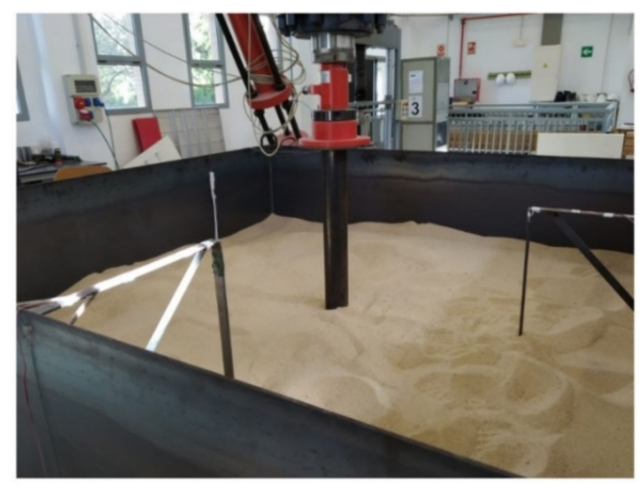

(a)

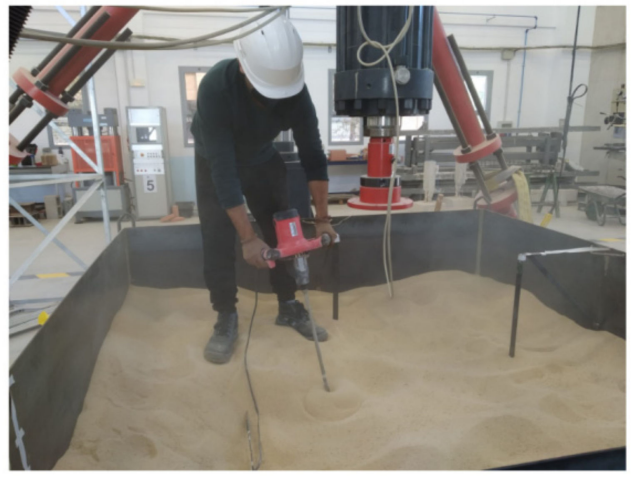

(b)

Figure 12. Project phases: (a) testing a pile of $80 \mathrm{~mm}$; (b) decompaction of the sand.

\section{Results}

The results obtained in the 18 tests are shown below. First, a comparison of the three tubes is shown for each velocity and type (H or F) (Figures 13-15).

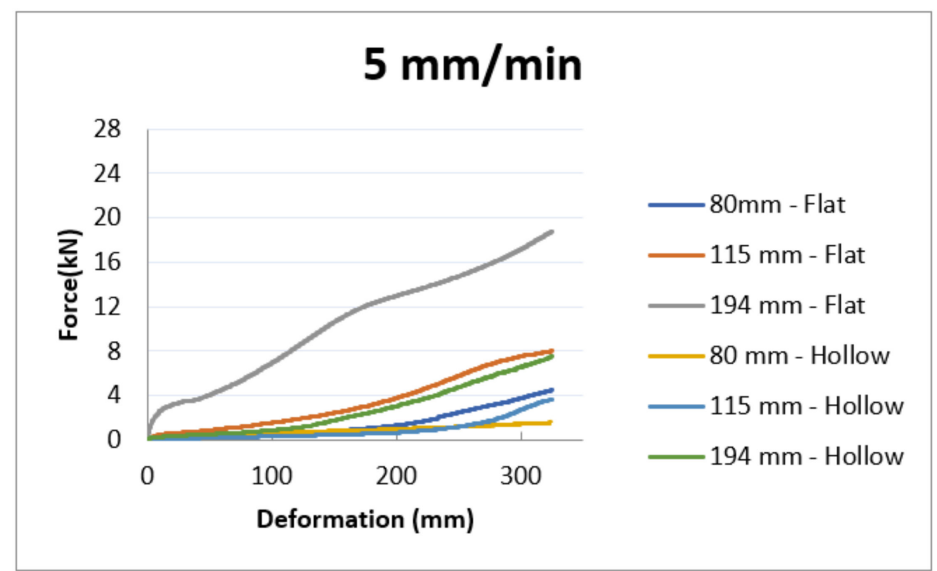

Figure 13. Deformation and force at each position for a speed of $5 \mathrm{~mm} / \mathrm{min}$.

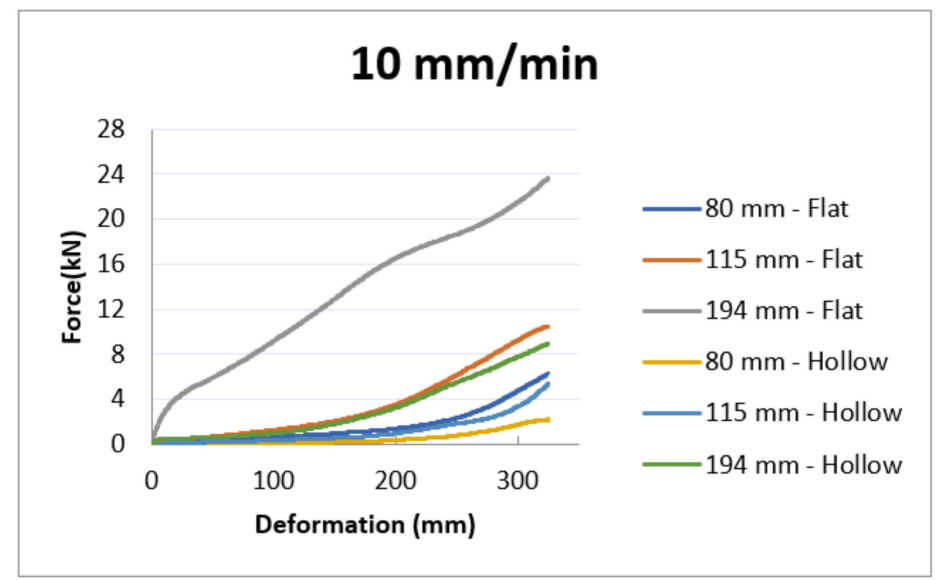

Figure 14. Deformation and force at each position for a speed of $10 \mathrm{~mm} / \mathrm{min}$. 


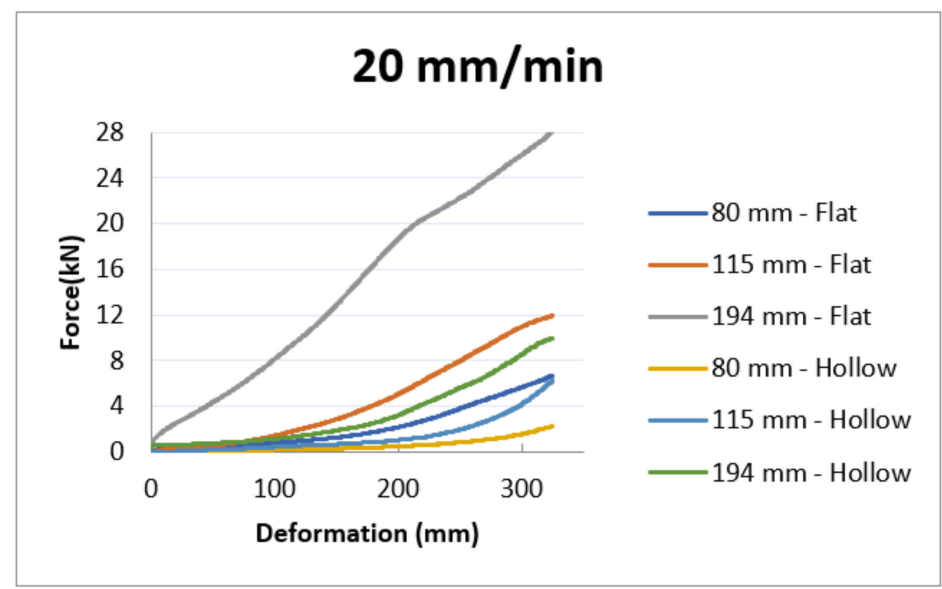

Figure 15. Deformation and force at each position for a speed of $20 \mathrm{~mm} / \mathrm{min}$.

Next, a comparison of the three speeds is shown for each tube and type ( $\mathrm{H}$ or $\mathrm{F})$ (Figures 16-18).

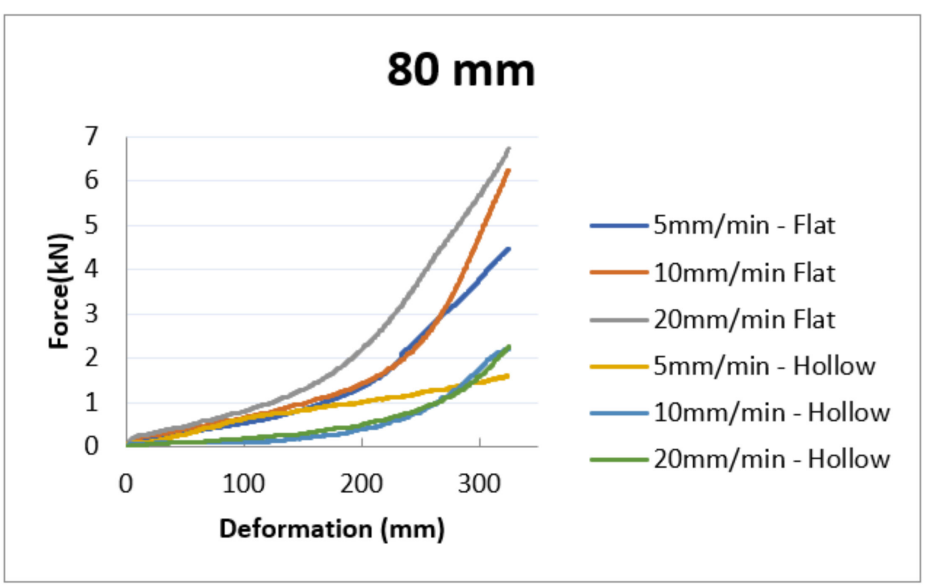

Figure 16. Deformation and force at each position for a diameter of $80 \mathrm{~mm}$.

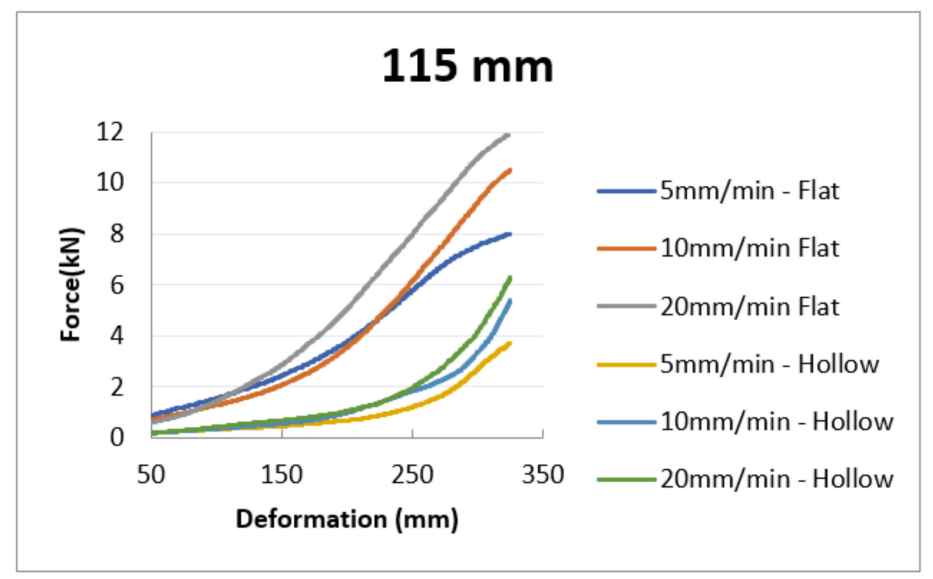

Figure 17. Deformation and force at each position for a diameter of $115 \mathrm{~mm}$. 


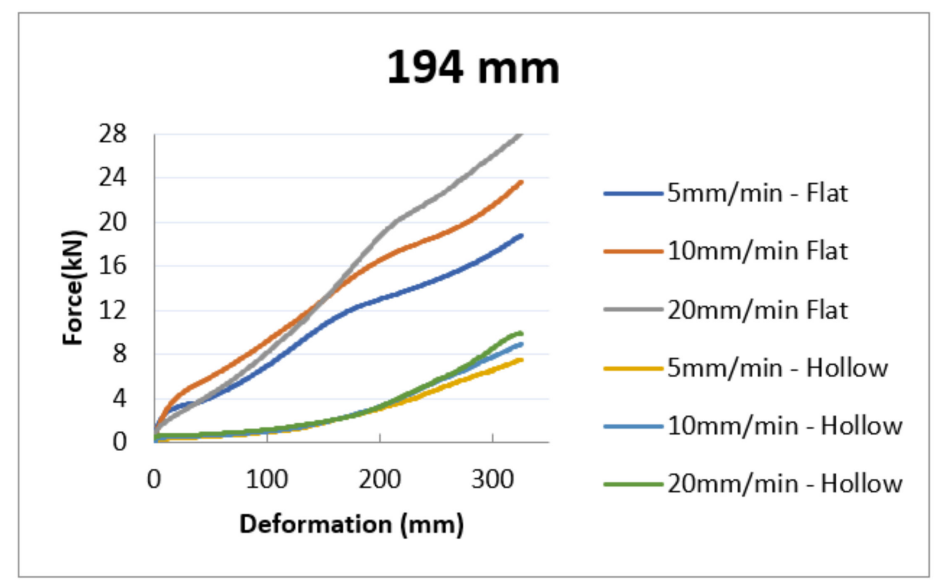

Figure 18. Deformation and force at each position for a diameter of $194 \mathrm{~mm}$.

These tests were conducted to obtain the penetration force of the driving length. Accordingly, we selected the tube, the tube position, and the penetration speed. The results are shown above.

It was verified that, for the same tube, a higher penetration speed would lead to greater force. On the other hand, it was verified whether a greater diameter of the tube led to a greater penetration force. These trials allowed the verification of both initial hypotheses [35,40].

The maximum value of penetration force obtained was $28.16 \mathrm{kN}$ for the case with $194 \mathrm{~mm}$ diameter in a flat position, and the minimum value obtained was $1.59 \mathrm{kN}$ for the case with $80 \mathrm{~mm}$ diameter in a hollow position.

A large amount of data were obtained from each test gauge (108 measurements). Figure 19 shows the most representative values of all measurements corresponding to Gauges 5 and 6 in the flat test. The hollow test presented smaller values than the flat test.

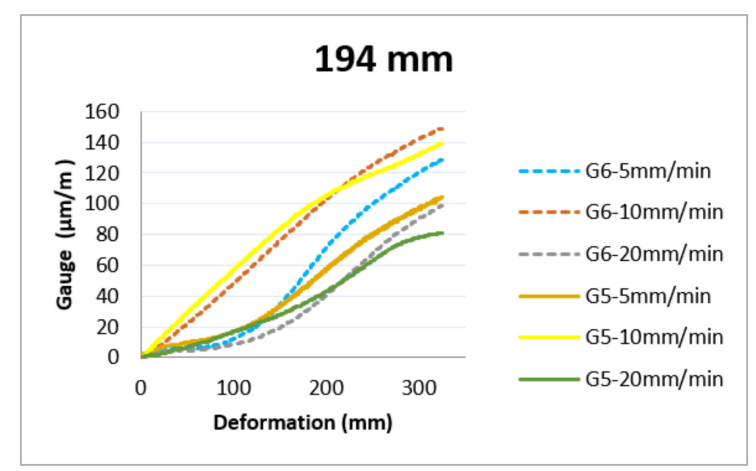

Figure 19. Deformation of Gauges 5 and 6 at each position for a diameter of $194 \mathrm{~mm}$.

\section{Discussion}

The results obtained across $325 \mathrm{~mm}$ of deformation are recapitulated in Tables 5 and 6 . These tables show the variation for each tube and each type.

Tables 5 and 6 and Figure 20 show that there is a relationship among the penetration speed, the obtained load, and the tube diameter. Taking the smallest value obtained as 1 , the relative increase could be determined for the other tubes or speeds.

Table 5 shows that the variation as a function of speed, with 1.19 or 1.46 greater values obtained at a speed of $10 \mathrm{~mm} / \mathrm{min}$ and 1.32 or 1.7 greater values obtained at a speed of $20 \mathrm{~mm} / \mathrm{min}$ with respect to $5 \mathrm{~mm} / \mathrm{min}$.

Table 6 instead shows the variation as a function of diameter, with 1.67 and 2.61 greater values obtained at a diameter of $115 \mathrm{~mm}$ and 3.77 and 4.74 greater values obtained at a diameter of $194 \mathrm{~mm}$ with respect to $80 \mathrm{~mm}$. 
Table 5. Values of penetration force for all scale tests as a function of speed.

\begin{tabular}{|c|c|c|c|c|c|c|}
\hline \multirow{2}{*}{ Speed $(\mathrm{mm} / \mathrm{min})$} & \multicolumn{2}{|c|}{ Tube $1(\varphi 80 \mathrm{~mm})$-Hollow } & \multicolumn{2}{|c|}{ Tube $2(\varphi 115 \mathrm{~mm})-$ Hollow } & \multicolumn{2}{|c|}{ Tube $3(\varphi 194 \mathrm{~mm})-$ Hollow } \\
\hline & Force $(\mathbf{k N})$ & Relation & Force $(\mathbf{k N})$ & Relation & Force $(\mathbf{k N})$ & Relation \\
\hline 5 & 1.59 & 1.00 & 3.71 & 1.00 & 7.53 & 1.00 \\
\hline 10 & 2.23 & 1.40 & 5.42 & 1.46 & 8.99 & 1.19 \\
\hline 20 & 2.41 & 1.52 & 6.29 & 1.70 & 9.91 & 1.32 \\
\hline \multirow{2}{*}{ Speed $(\mathrm{mm} / \mathrm{min})$} & \multicolumn{2}{|c|}{ Tube $1(\varphi 80 \mathrm{~mm})$-Flat } & \multicolumn{2}{|c|}{ Tube $2(\varphi 115 \mathrm{~mm})$-Flat } & \multicolumn{2}{|c|}{ Tube $3(\varphi 194 \mathrm{~mm})$-Flat } \\
\hline & Force $(\mathbf{k N})$ & Relation & Force $(\mathbf{k N})$ & Relation & Force $(\mathbf{k N})$ & Relation \\
\hline 5 & 4.48 & 1.00 & 8.00 & 1.00 & 18.81 & 1.00 \\
\hline 10 & 6.27 & 1.40 & 10.50 & 1.31 & 23.64 & 1.26 \\
\hline 20 & 6.71 & 1.50 & 11.94 & 1.49 & 28.15 & 1.50 \\
\hline
\end{tabular}

Table 6. Values of penetration force for all scale tests as a function of diameter.

\begin{tabular}{|c|c|c|c|c|c|c|}
\hline \multirow{2}{*}{ Diameter (mm) } & \multicolumn{2}{|c|}{ Speed $5 \mathrm{~mm} / \mathrm{min}-$ Hollow } & \multicolumn{2}{|c|}{ Speed $10 \mathrm{~mm} / \mathrm{min}-$ Hollow } & \multicolumn{2}{|c|}{ Speed $20 \mathrm{~mm} / \mathrm{min}-$ Hollow } \\
\hline & Force $(\mathbf{k N})$ & Relation & Force $(\mathbf{k N})$ & Relation & Force $(\mathbf{k N})$ & Relation \\
\hline 80 & 1.59 & 1.00 & 2.23 & 1.00 & 2.41 & 1.00 \\
\hline 115 & 3.71 & 2.33 & 5.42 & 2.43 & 6.29 & 2.61 \\
\hline 194 & 7.53 & 4.74 & 8.99 & 4.04 & 9.91 & 4.11 \\
\hline \multirow{2}{*}{ Diameter (mm) } & \multicolumn{2}{|c|}{ Speed $5 \mathrm{~mm} / \mathrm{min}-$ Flat } & \multicolumn{2}{|c|}{ Speed $10 \mathrm{~mm} / \mathrm{min}$-Flat } & \multicolumn{2}{|c|}{ Speed $20 \mathrm{~mm} / \mathrm{min}$-Flat } \\
\hline & Force $(\mathbf{k N})$ & Relation & Force $(\mathbf{k N})$ & Relation & Force $(\mathbf{k N})$ & Relation \\
\hline 80 & 4.48 & 1.00 & 6.27 & 1.00 & 6.71 & 1.00 \\
\hline 115 & 8.00 & 1.79 & 10.50 & 1.67 & 11.94 & 1.78 \\
\hline 194 & 18.81 & 4.19 & 23.64 & 3.77 & 28.15 & 4.20 \\
\hline
\end{tabular}

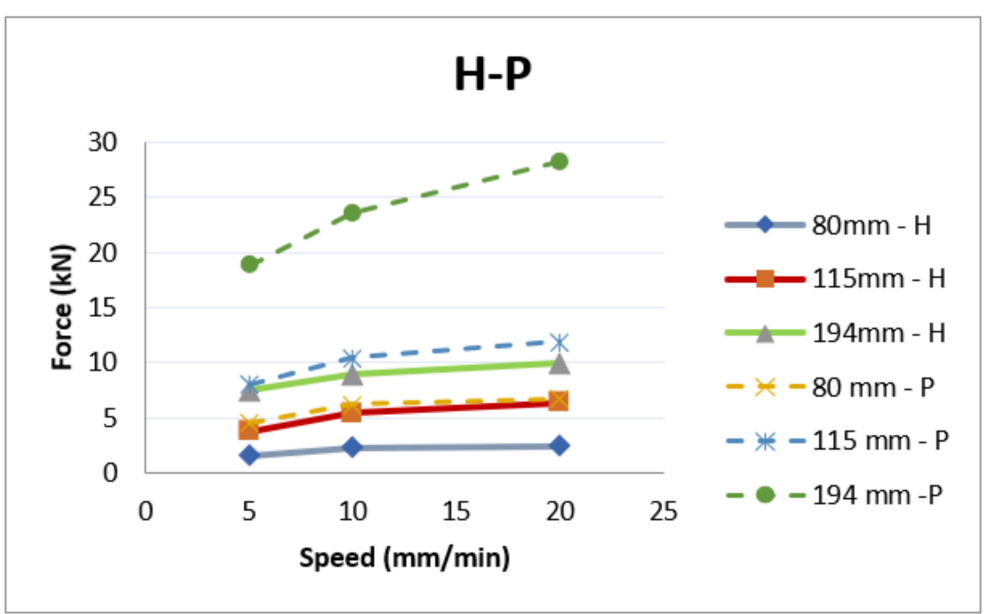

Figure 20. Maximum value of force at each position, speed, and diameter.

\section{Conclusions}

The graph in Figure 20 shows that, for the same tube, a greater speed required a greater force to achieve the same penetration [28]. For example, for a tube in a flat position with $80 \mathrm{~mm}$ diameter and a speed of $5 \mathrm{~mm} / \mathrm{min}$, a force of $4.48 \mathrm{kN}$ was obtained; in contrast, at a speed of $20 \mathrm{~mm} / \mathrm{min}$, a force of $6.71 \mathrm{kN}$ was obtained.

For the same tube, the variation of load application defined the behavior of the penetration force for the same deformation. For example, for an $80 \mathrm{~mm}$ tube in a flat position, there was a 1.5 ratio between the speeds of $20 \mathrm{~mm} / \mathrm{min}$ and $5 \mathrm{~mm} / \mathrm{min}$. This relationship held for all tubes. 
In addition, there were differences in the results obtained for the hollow and flat situations. For flat penetration, a greater force was required to achieve the same drive length, which is a vital factor to take into account when designing offshore structures.

In terms of diameter, the force/diameter ratio for tubes 1 and 3 was $4 / 2.4=1.67$. This ratio is important for the estimation of penetration force values for larger-diameter tubes such as those used in offshore foundations.

Author Contributions: Conceptualization, J.S.V. and J.G.B.; Methodology, J.S.V. and J.G.B.; Software, J.S.V. and J.G.B.; Validation, J.S.V. and J.G.B.; Formal analysis, J.S.V., J.G.B., J.L.F. and V.N.V.; Investigation, J.S.V., J.G.B., J.L.F. and V.N.V.; Resources, J.L.F. and V.N.V.; Data curation, J.L.F. and V.N.V.; Writing—original draft preparation, J.S.V. and J.G.B.; Writing—review and editing, J.S.V., J.G.B., J.L.F. and V.N.V.; Visualization, J.L.F. and V.N.V.; Supervision, J.S.V., J.G.B., J.L.F. and V.N.V.; Project administration, J.S.V. and J.G.B.; Funding acquisition: J.S.V. and J.G.B. All authors have read and agreed to the published version of the manuscript.

Funding: This research received no external funding.

Conflicts of Interest: The authors declare no conflict of interest.

\section{References}

1. Luengo Frades, J.; Negro Valdecantos, V.; García Barba, J.; Lopez Guiterrez, J.S.; Esteban, M.D. Offshore Wind Energy. Create a Lot of Questions. Give Some Answers. Renew. Energy 2019, 131, 667-677.

2. Esteban, M.D.; Diez, J.; López, J.S.; Negro, V. Why offshore wind energy? Renew. Energy 2011, 36, 444-450. [CrossRef]

3. Luengo Frades, J.; Negro, V.V.; García Barba, J.; Soriano Vicedo, J.; Martín-Antón, M. Blue Economy: Compatibility between the Increasing Offshore Wind Technology and the Achievement of the SDG. J. Coast. Res. 2020, 95, 1490-1494. [CrossRef]

4. Lam, I.P.O. Diameter Effects on p-y Curves. Deep Marine Foundations-A Perspective on the Design and Construction of Deep Marine Foundations. In Proceedings of the Third International Symposium on Frontiers in Offshore Geotechnics (ISFOG 2015), Oslo, Norway, 10-12 June 2015.

5. DNVGL-ST-0126. Support Structure for Wind Turbines; DNV: Bærum, Norway, 2016.

6. API. RP 2A-WSD—Recommended Practice for Planning, Designing and Constructing Fixed Offshore Platforms; American Petroleum Institute: Washington, DC, USA, 2010.

7. Arroyo, M.; Abadías, D.; Alcoverrro, J.; Gens, A. Shallow Foundations for Offshore Wind Towers. In Proceedings of the 18th International Conference on Soil Mechanics and Geotechnical Engineering, Paris, France, 2-6 May 2013.

8. Butlanska, J.; Arroyo, M.; Gens, A. Steady State of Solid-Grain Interfaces During Simulated CPT. Studia Geotech. Mech. 2013, 35, 13-22. [CrossRef]

9. Randolph, M.F. Science and Empiricism in Pile Foundation Design. Géotechnique 2003, 53, 847-875. [CrossRef]

10. Bülow, L.; Jorgensen, L.; Gravessen, H. Kriegers Flak Offshore Wind Farm. Basic Data for Conceptual Design of Foundations; Vattenfall Vindkraft AB: Solna, Sweden, 2009.

11. Lesny, K. Foundations for Offshore Wind Turbines: Tools for Planning and Design; VGE: Essen, Germany, 2010.

12. Lesny, K. Design Approaches of Eurocode 7 and their Effect on the Safety of Shallow Foundations. In ICASP10, Applications of Statistics and Probability in Civil Engineering; Taylor \& Francis: Abingdon-on-Thames, UK, 2007.

13. Passon, P.; Branner, K.; Larsen, S.E.; Hvenekær Rasmussen, J. Offshore Wind Turbine Foundation Design. Ph.D. Thesis, PDTU Wind Energy, Technical University of Denmark, Kgs. Lyngby, Denmark, 2015.

14. Luengo Frades, J.; Negro Valdecantos, V.; García Barba, J.; Lopez Guiterrez, J.S.; Esteban, M.D. New Detected Uncertainties in the Design of Foundations for Offshore Wind Turbines. Renew. Energy 2019, 131, 667-677. [CrossRef]

15. Byrne, B.W.; McAdam, R.; Burd, H.J.; Houlsby, G.T. PISA- New Design Methods for Offshore Wind Turbines. In Proceedings of the 8th International Conference, Royal Geographical Society, London, UK, 12-14 September 2017.

16. Taborda, D.M.G.; Zdravkovi, L.; Kontoe, S.; Potts, D.M. Computational Study on the Modification of a Bounding Surface Plasticity Model for Sands. Comput. Geotech. 2014, 59, 145-160. [CrossRef]

17. Chow, F.C. Investigations into the Behaviour of Displacement Piles for Offshore Foundations. Ph.D. Thesis, Imperial College, London, UK, 1997.

18. Jardine, R.J.; Standing, J.R.; Chow, F.C. Some Observations of the Effects of Time on the Capacity of Piles Driven in Sand. Géotechnique 2006, 554, 227-244. [CrossRef]

19. Lopez, I.; Lopez, M.; Aragones, L.; García-Barba, J.; Lopez, M.P.; Sánchez, I. The Erosion of the Beaches on the Coast of Alicante: Study of Themechanisms of Weathering by Accelerated Laboratory Tests. Sci. Total Environ. 2016, 567, 191-204. [CrossRef] [PubMed]

20. Guillen, J.; Hoekstra, P. The Equilibrium Distribution of Grain Size Fractions and its Implications for Cross-Shore Sediment Transport: A conceptual model. Mar. Geol. 1996, 135, 15-33. [CrossRef]

21. UNE-EN 933-1 Standard. Ensayos para Determinar las Propiedades Geométricas de los Áridos (Tests to Determine the Geometric Properties of Aggregates); Spanish Association for Standardisation-UNE: Madrid, Spain, 2012. 
22. UNE 103101:1995 Standard. Análisis Granulométrico de Suelos por Tamizado. (Article Size Analysis of a Soil by Screening); Spanish Association for Standardisation-UNE: Madrid, Spain, 1995.

23. ASTM D6913/D6913M-17. Standard Test Methods for Particle-Size Distribution (Gradation) of Soils Using Sieve Analysis; ASTM International: West Conshohocken, PA, USA, 2017.

24. Lopez, I. Clasificación Morfológica de las Playas y Modelado del Perfil Transversal en Valencia, Alicante y Muercia. Ph.D. Thesis, Universidad Alicante, San Vicente del Raspeig, Spain, 2016.

25. Almazán Gárate, J.L.; Palomino Monzón, M.C.; García Montes, J.R. Introducción a la Dinámica de las Formas Costeras; Universidad Politécnica de Madrid: Madrid, Spain, 2000.

26. UNE-EN 1097-6 Standard. Ensayos para Determinar las Propiedades Mecánicas y Físicas de los Aridos. Parte 6: Determinacion de la Densidad de Partículas y la Absorción de Agua (Tests to Determine the Mechanical and Physical Properties of Aggregates); Spanish Association for Standardisation-UNE: Madrid, Spain, 2014.

27. UNE 103401 Standard. Determinación de los Parámetros Resistentes al Esfuerzo Cortante de una Muestra de Suelo en la Caja de Corte Directo (Determination of the Shear Resistant Parameters of a Soil Sample in the Direct Cutting Box); Spanish Association for Standardisation-UNE: Madrid, Spain, 1998.

28. Soriano Vicedo, J.; Luengo Frades, J.; García Barba, J.; Negro Valdecantos, V. Modified Soil Test for Scour Analysis on Offshore Windfarm Foundations. Trans. Eng. Sci. 2019, 125, 185-194.

29. UNE-EN ISO 17892-9:2019 Standard. Investigación y Ensayos Geotécnicos. Ensayos de Laboratorio de Suelos. Parte 9: Ensayos de Compresión Triaxial Consolidados en Suelos Saturados de Agua (Geotechnical Investigation and Testing-Laboratory Testing of Soil-Part 9: Consolidated Triaxial Compression Tests on Water Saturated Soils. Part 6: Determination of Particle Density and Water Absorption); Spanish Association for Standardisation-UNE: Madrid, Spain, 2019.

30. Alexa Calderón Goyeneche, L.; Mayerly Argüello Romero, D. Estado del Arte del Uso del Ensayo spt Con Fines de Correlación de Parametros Mohr-coulomb; Universidad Católica de Colombia: Bogota, Colombia, 2014.

31. Latini, C.; Zania, V. Triaxial Tests in Fontainebleau Sand; Technical University of Denmark: Kongens Lyngby, Denmark, 2016.

32. Tatsuoka, F.; Sato, T.; Park, C.; Kim, Y.S.; Mukabi, J.N.; Kohata, Y. Measurements of Elastic Properties of Geomaterials in Laboratory Compression Tests. Geotech. Test. J. 1994, 17, 80-84.

33. UNE-EN ISO 6892-1:2020 Standard. Materiales metálicos. Ensayo de tracción. Parte 1: Método de Ensayo a Temperatura Ambiente (Metallic Materials-Tensile Testing_Part 1: Method of Test at Room Temperature); Spanish Association for Standardisation-UNE: Madrid, Spain, 2020.

34. UNE 103502 Standard. Método de Ensayo para Determinar en Laboratorio el Índice C.B.R de un Suelo (Test Laboratory Method for Determining in a Soil the c.b.r. Index.); Spanish Association for Standardisation-UNE: Madrid, Spain, 1995.

35. Song Dai, B.H.; Guoxiang, H.; Xiaoqiang, G.; Liu, J.; Shiliang, L. Failure Mode of Monopile Foundation for Offshore Wind Turbine in Soft Clay Under Complex Loads. Mar. Georesour. Geotechnol. 2020, 1-12. [CrossRef]

36. Kelly, R.B.; Houlsby, G.T.; Byrne, B.W. A comparison of field and laboratory caisson tests in sand and clay. Géotechnique 2006, 9 , 617-626. [CrossRef]

37. Butlanska, J.; Arroyo, M.; Gens, A.; O'Sullivan, C. Multi-scale analysis of cone penetration test (CPT) in a virtual calibration chamber. Can. Geotech. J. 2014, 51, 51-66. [CrossRef]

38. Phuong, N.T.V.; Van Tol, A.F.; Elkadi, A.S.K.; Rohe, A. Numerical investigation of pile installation effects in sand using material point method. Comput. Geotech. 2016, 73, 58-71. [CrossRef]

39. Jiang, M.J.; Harris, D.; Zhu, H.H. Future continuum models for granular materials in penetration analyses. Granul. Matter 2007, 9 , 97-108. [CrossRef]

40. Gurevitz Esposito, R.; Quadros Velloso, R.; Amaral Vargas, E.; Ragoni Danziger, B. Multi-scale sensitivity analysis of pile installation using DEM materials in penetration analyses. Comput. Part. Mech. 2018, 5, 375-386. [CrossRef] 